\section{Autonomy beyond reach}

POLISH universities opened last week in somewhat gloomy circumstances. The Party daily, Trybuna Ludu, greeted the new term by observing that "for several years, the intellectual activity of the academic milieu has been declining" and has failed to produce "fresh achievements significant in world standards".

At the same time, the paper gave a strong hint that the autonomy of the universities was, essentially, part of an implicit bargain by which the university authorities, in their turn, assumed "co-responsibility" to prevent university self-governance being used as a cloak for "harmful" actions.

Neither of these criticisms is unexpected. The declining standards of Polish science have been repeatedly discussed, explained and excused in the Polish press during the past year, and may fairly be summed up as the result of the hierarchical planning of research during the Gierek regime (when every research project had, officially, to relate to a carefully graded ladder of "problems", of the national economy). But, now, all foreign currency for the purchase of equipment and journals has suddenly been cut off. The situation is so bad, a working party of the Polish Academy of Sciences warned last month, that without an immediate injection of hard currency, Polish science could come to a complete halt.

University autonomy has also been a contentious issue during the past year. The chief clash was over the election of university rectors, when three rectors-elect were vetoed by the Minister for Science, Higher Education and Technology, Dr Benon Miskiewicz; when the Warsaw University electoral college refused to accept his decision, its functions were suspended for six months and the minister let it be understood that he would appoint a rector of his own choosing. Yet when the university opened last week, the outgoing rector, Dr Kazimiedrz Dobrowolski, presided over the beginning-of-term ceremonies and, in his inaugural address, expressed the hope that the university would soon have a new rector, chosen by the electoral college.

It is now thought that Dr Dobrowolski came to an agreement with the minister during the vacation, by which he would continue in office until 15 February 1985 , and that the electoral college would elect his successor when its term of suspension expires in February. But none of this has appeared in the Polish press, and there is no certainty that, even if there is another election, the minister will not again intervene if the choice is too "daring".

The issues of autonomy and of research standards are, in fact, related, since one of the major demands for academic autonomy formulated in the Solidarity period was the right of universities to determine their own research programmes, inde- pendently of state priorities. But even the autonomy granted by the 1982 Higher Education Act (considerably less farreaching than was originally hoped for) is not always easy to implement. In a recent interview in Polibyka the rector of the Jagiellonian University of Krakow, Dr Józef Gierowski, noted that university selfgovernment cannot be invoked to deal with the bottom-heavy structure of academic teaching staff, where too few assistants and junior lecturers are prepared to qualify themselves for professional posts.

The university, he explained, "being as it were a continuation of the function of the welfare state", is obliged to employ "scientific workers", for whom the PhD degree represents the "peak of their capacity or ambition". (Senior academic staff in Poland must hold the higher degree of doctor habilitatus). The only success for "autonomy" in dealing with such people is the acceptance of the principle that they must resign if they do not get their doctorate within eight years.

Polityka, which, although less liberal than before Martial Law, still enjoys considerable prestige, has during the past year given considerable space to problems of science and education. Recently it has been particularly concerned with the training of Poland's future scientific workforce, covering such issues as the falling interest among university entrants in the technical engineering sciences, the challenge of the "third wave", the relevance of "new maths" in primary schools, and the practice, recently introduced in some schools, of a longer school-day with Saturdays free.
Vera Rich

\title{
US-Japanese education
}

\section{One man's meat, another's poison}

\section{Tokyo}

JAPAN and the United States have agreed to set up a joint 30 -member council to compare their educational systems from May of next year. The move comes not before time, for both nations have been worrying about the weaknesses of their respective systems (helped along by reports of emerging IQ differences) and envying the strengths - real and imagined - of the other's.

At the Washington meeting between Japan's Education Secretary Yoshiro Mori and US Secretary of Education Terrel $\mathbf{H}$. Bell that gave approval to the council, Bell, reflecting growing US desires for a return to a more disciplined educational system, lavished praise upon Japan's tough juku (private cramming school) system, saying that the United States "must have juku because the Japanese are so productive".

A horrified Mori then had quickly to explain that the Japanese Government, reflecting growing desires for a more liberal educational system, regards private cramming schools, at which some students spend four hours a night, as an evil produced by the terrible competition for entry to leading universities and high schools, and hopes to do away with them. Later, Bell, well known as a supporter of increased homework in US schools, admitted that he had not actually known what $j u k u$ were but what he really wanted was a longer school day "which is a supervised, studying, tutoring, juku-type thing"' (sic).

The US-Japan council will have its first meeting in Tokyo and will have a special panel looking at problems of science and mathematics education - of particular concern to the United States. Experts from the United Kingdom, France and Germany are also to be invited.

Shortly before Mori's meeting with Bell,
Japan's Prime Minister, Yasuhiro Nakasone, finally succeeded, after six months of Diet wrangling (see Nature 308, 678 and 309,$739 ; 1984)$, in inaugurating the special council which is to spend three years devising reforms of Japan's education system.

Despite vociferous protests from the socialist and communist parties, the council has been handpicked by Nakasone and is answerable directly to him. Only two school-teachers are among the council's 25 members (average age 60) and there are no representatives from the nation's biggest teachers' organization, the Japan Teachers Union, which virtually ensures that conflict will continue. The post of president of the council has, however, gone to a well known liberal, Professor Michio Okamoto, until recently president of Kyoto University. Nakasone has asked the council to take speedy action on the biggest problem - the university entrance examination - and to seek "diversity" in the education system.

Exactly what diversity means is likely to cause considerable debate. In the present straight "one-track" educational system, completely unstreamed groups study the same subjects and try the same examinations, with only total scores deciding how a distinguished university faculty can be entered (and thus often what subject is studied). The liberals would replace it with one in which students have freedom to follow their own interests and receive an education tailored to their own particular abilities, but what the left wing fears is that "diversity" will simply mean increasing the scale of divisions between top quality (and expensive) private schools and the poorer state schools: an effective return to a prewar system where elites were selected for special training at an early age.

Alun Anderson 